\title{
The Underground Railroad As Afrofuturism: Enslaved Blacks Who Imagined A Future And Used Technology To Reach The "Outer Spaces of Slavery"
}

\author{
Dann J. Broyld ${ }^{1}$ \\ Central Connecticut State University, New Britain, Connecticut, United States
}

\begin{abstract}
This article employs the lens of Afrofuturism to address the Underground Railroad, detailing what imagination, tact, and technology, it took for fugitive Blacks to flee to the "outer spaces of slavery." Black enslavement was as terrifying as any exotic fictional tale, but it happened to real humans alienated in the "peculiar institution." Escaping slavery brought dreams to life, and at times must have felt like "magical realism," or an out-of-body experience, and the American North, Canada, Mexico, Africa, Europe, and free Caribbean islands were otherworldly and science fiction-like, in contrast to where Black fugitives ascended. This article will address the intersections of race, technology, and liberation, by retroactively applying a modern concept to historical moments.
\end{abstract}

Keywords: Afrofuturism, Enslavement, Technology, Underground Railroad.

\section{Introduction}

The superhero film Black Panther, based on the Marvel Comic and distributed by Walt Disney, premiered in 2018 rose to be one of the highest grossing motion pictures of all time, and it showcased the concept of Afrofuturism. The film's Black director, Ryan Coogler, and its Black cast starring Chadwick Boseman as T'Challa, created a cultural phenomenon at theaters around the world, particularly among those of the African Diaspora. The philosophy of Afrofuturism which is, put simply, the intersections of race, innovation, and technology to visualize future liberation, relates directly to the fictional nation of Wakanda and the real Underground Railroad with its "conductors" and "passengers" (Womack, 2013; Anderson and Jones, 2017). In fact, in Black Panther's climax, the final fight between T'Challa and his antagonist Erik Killmonger took place on an underground railroad with trains dashing by, evoking a familiar historical reference (Lebron, 2018; Wallace, 2018). This scene prompted my thoughts about the real Blackled Underground Railroad, named after the latest transportation advancement, and how this network was the enactment of early Afrofuturism for enslaved people in the American South.

After all, being othered by society as a slave was alienating and the toil robotic. Blacks transported in the Middle Passage to those living throughout the Civil War era all felt ostracize by the devices of enslavement. However, escaping slavery brought imagination to life, and at times must have felt like "magical realism," or an out-of-body experience, and the American North, Canada, Mexico, Africa, Europe, and free Caribbean islands were otherworldly and science fiction-like, in contrast to where they ascended. For running away, involved fighting alien technologies like the telegraph, unknown to little known letters and words, advertisements sought to recapture, countering a formidable adversary that used modernity as its tools, and imagining spaces where they could innovate, flourish, and invoke the cultures of the African continent. Fugitive enslaved Blacks, casted as "illegal aliens," employed the North Star to take flight to what seem to be nirvana or galaxies away a "Free State," the "Promised Land" Canada, or other "outer spaces of slavery." The Underground Railroad also divorced the "long-lasting marriage of transportation and oppression," transforming it into a Black liberation force (Bhimull, 2017, 67).

This article employs the lens of Afrofuturism to reimagine the Underground Railroad concept and those seeking freedom by flight. It details what imagination, tactical codes and deception, the dynamic journey North or to other locations, and fantasy of future, it took to even attempt to flee. Black enslavement was as terrifying as any exotic fictional tale, but it happened to real humans. In fact, Josiah Henson, also known as "Uncle Tom," titled one of his narratives Truth Stranger Than Fiction and Peter Bruner titled his A Slave's Adventures Toward Freedom. Not Fiction, But the True Story of a Struggle (Henson, 1858; Bruner, 1918). The objective is to be substantive about actual "human property" enslaved in the "peculiar institution" with the conviction of a free future. The study is grounded in firstperson narratives of the formerly enslaved, fictional neo-slave narratives, and makes reference to other fictional texts (Gates, 1984; Andrews, 2019, 1988; Rushdy, 1999; Goyal, 2019). Together they demonstrate that Blacks engaged with

${ }^{1}$ Associate Professor, Department of History, Public History and African American History Specialist, Email: d.broyld@ccsu.edu. 
inventions such as Eli Whitney's cotton gin and like others of their day were fascinated or had "railroad fever" and "future shock" with the iron horses racing through the nation moving people and commodities at a rapid pace predominately in the industrial futuristic American North (Jameson, 1982, 151; Carrington, 2016).

The article will examine the questions of: Were enslaved Blacks Afrofuturists? How can Afrofuturism be used to grasp the tangible Underground Railroad network and its attached American mythology? And how does the Railroad comprehensively mix modernity, fairytale, and actual movement of Black fugitives? It will first define Afrofuturism for the historical and mythological Underground Railroad. Second, it examines the visions of future that enslaved Blacks possessed and the superhero-like flights they took to liberate themselves. And lastly, it discusses the Black inner geeks that used tools and technology to guide them to the "outer spaces of slavery." The article adds to the conversation of Afrofuturism by retroactively applying it, to recast Black resistance and to show how astute fugitives fought the ultimate algorithm of enslavement via running away.

The Underground Railroad and Afrofuturism pair well together as they are part of the long arc of the Black freedom struggle. Stories told by enslaved Africans about the Middle Passage to the "New World" must have sounded like Jazz artist Sun Ra's tale of being teleported to Saturn or like Elijah Muhammad of the Nation of Islam describing the extraterrestrial "mother plane" composed of spheres within spheres described by the biblical prophet Ezekiel (Kelley, 2003; Mayer 2000). The Negro Spirituals or "Sorrow Songs" of Blacks crafted out of necessity are dotted with coded messaging of the Negro grapevine that reflect Psychedelic Funk, which was developed in the 1960s and 1970s when outer space was being conceptualized as an escape from social and political bigotry on earth (Washington, 1901, 8). "Swing Low, Sweet Chariot," for example, re-conceptualized by George Clinton and ParliamentFunkadelic's "Mothership," was a call to lift Blacks out of oppression (Harriston, 2017). "General" Harriet Tubman, the "Moses" of her people, could easily fit within the ranks of Black Panther's Dora Milaje, a team of special force women who protect Wakanda (Spencer, 2018). Slavecatcher Ridgeway of Colson Whitehead's alternate history novel The Underground Railroad is the adversary that fugitives sought to sidestep (Whitehead, 2016). They looked to steampower, constellations, and sailors for guidance to a new future. In all, Afrofuturism challenges its audience to grapple with the notion that "if you can create a new vision of the future, you can create a new vision of the past" as professor and artist D. Denenge Akpem asserted (Womack, 2013, 154).

\section{Afrofuturism Defined for the Historical and Mythological Railroad}

The term Afrofuturism was developed in North America and subsequently spread throughout the African Diaspora. It was coined in the early 1990s by author and cultural critic Mark Dery in an interview he conducted with semiotician Samuel Delany, writer and critic Greg Tate, and Africana Studies professor Tricia Rose later titled "Black to the Future" (Dery, 1994). It helps to define the musical and cultural production of individuals such as Sun Ra and George Clinton and sci-fi writers like Samuel L. Delany, Octavia Bulter, Charles Saunder, and Steve Barnes (Kreiss, 2012; Steinskog, 2017; Youngquist, 2016; Szwed, 1998). Their works displayed the intersection between African Diaspora cultures and technology. Afrofuturism can be defined "as a way of imagining possible futures through a black cultural lens...to encourage experimentation, reimagine identities, and activate liberation" (LaFleur, 2011; Womack, 2013, 9). Thereby, its befitting of the Underground Railroad. Afrofuturism challenges Eurocentric motifs and asks critical questions of alienation, colonialism, racism, sexism, and a wealth of exploitive "isms." It also interrupts mainstream and canonized Science Fiction, liberating Blacks from nonexistence and background positions. Dery stated that the genre was a "Boys Club. Girls, keep out. Blacks and Hispanics and the poor in general, go away" (Dery, 1994, 188; James, 2019; Lavender, 2011).

Afrofuturism has emerged to encompass cultural analytics, metaphysics, aesthetics, cosmology, anthropomorphic art, visual studies, speculative philosophy, and Astro-Blackness. Like technology, Afrofuturism is often upgraded. Historian Patrick Manning explained that Black culture "renews itself repeatedly through new technology, new audiences, improvisation, and continued borrowing" (Manning, 2010, 34). Afrofuturism has taken cues from intellectuals such as Nathan Hare and James Stewart, has given rise to a Black Speculative Art Movement, and has been taken to deeper theoretical and analytical depths by a robust number of scholarly works (Eshun, 1998; Nelson, 2002; Weheliye, 2005; Barr, 2008; Jackson \& Moody-Freeman, 2013; Phillip, 2015; Anderson \& Jones, 2016; van Veen \& Anderson, 2018). Of course, there are productive tensions and different outlooks on Afrofuturism, for instance on the postcolonial and post-apocalyptic visions of Blackness (Yu Burnett, 2015; Smith, 2012; Langer, 2011; Hopkinson \& Uppinder, 2004; Jue, 2017; Nnedi, 2014, 2019). Despite diverse approaches, the popularity of Afrofuturism is apparent in the growing number of academic conferences on the topic, in music concerts like AfroPunk hosted in Brooklyn, Atlanta, London, Paris, and Johannesburg and in the wealth of art installations materializing throughout the diaspora. Black Panther injected Afrofuturism with new energy and a wider audience. All of this cultural production is well-equipped for the future ethnic and racial studies. 
Afrofuturists view race as professor and medical-ethics Dorothy Roberts explained as a "fatal invention," but not a "default biological category;" because it has real historical, social, and political ramifications (Roberts, 2012; Womack, 2013, 27-28). Many assess "race as technology" and as visual artist John Jennings explained "everything is a type of technology" meaning that race is machinery constructed and institutionalized as a mechanism to entangle and oppress Black people (Gates, 1984, 59-80). Scholar Beth Coleman explained "race as technology recognizes the proper place of race not as a trait but as a tool—for good or for ill." She expounded, "the mechanism of race...is not a metal or wood contraption, but rather a thing that functions systematically." Indeed, race has "tool-like properties" which manifest via groups, governments, practices, and laws that deem Blacks sub-human (sambo) or super-human (superhero), but not quite fully human; that is why the calls for civil rights, human rights, and "Black Lives Matter" are efforts to simply regard Blacks as human, like their counterparts (Coleman, 2009, 184-185, 189-190, \& 199).

To deconstruct the apparatus of "race as technology" is a matter of combatting internal and external forces that "deliberately rubbed out" or unplugged Blacks from their motherboard, and to rewire thoughts and actions into circuit breakers of change and new spaces. The philosophy of Afrofuturism is applicable to slavery because it was engineered to produce cash crops at the expense of "alien" Black people in a colonial, capitalistic, and systematic way by means of the Triangular Trade (Luckhurst, 1998). However, the Underground Railroad proved that Blacks were technologist themselves able to counter the technicalities and logistics legislated against them. In other words, Blacks were not primitive or backwards and they could compute to undermine "slavery's dehumanization program" (Anderson and Jones, 2016, xvii) Today's Afrofuturists tackle notions of "recovery" and "draw power from the futures they endorse," much like the fugitive runaway did (Latham, 2017, 459-460). Afrofuturism rewrites the Black narrative to reveal the "hidden transcript" of resistance and to invoke Black empowerment as a factor to the plot (Scott, 1985, 1990). Although Afrofuturism has recently received more scholarly attention, it is truly outright historical and reflective of the Underground Railroad, both the "conductors" and the runaways who were its "passengers."

The origin of the name Underground Railroad is important to note as it mixes together reality and myth. It is believed that the name came from fugitive slave Tice Davids of Kentucky, who fled in 1831 by swimming the Ohio River with his master in close pursuit. He reached the shore of Ripley, Ohio, a hotbed of fugitive activity, and was unable to find Davids, as legend has it, the owner declared that he "must have gone off on an underground railroad" (Blight, 2006, viii-xi). Whatever the case running away signified optimism for an imagined future of freedom. All the tropes of the railroad were employed: from "tracks," "stations," or "depots" to "conductors," "agents," and "station masters." Escaped enslaved individuals were titled "passengers," "cargo," "freight" even "black ink" and the "finest coal;" they traveled with "tickets" and stopped at "terminals" on "Freedom Trails." The operation was funded by "stockholders" (Bordewich, 2005, 236-239). All these 19th century "techie terms" were changed from their original meanings to coded messages or double talk aimed at creating a system to transport Blacks to new spaces outside of enslavement zones. Historically, the Underground Railroad has been clouded with misconceptions--stories of secret quilts; hidden passageways and doors that did not exist; discourse on Canada as a "Promise Land;" and early oral histories that were retold over time without validation (Tobin, Dobard, \& Maude S. Wahlman, 2000; Frost, 2007; Hepburn, 1999; Kang, 2005; \& De B'Beri, Reid-Maroney, \& Wright, 2014).

Nonetheless, the traditional notion is that the Underground Railroad was a well-organized network of devoted conductors with secret codes and symbols, as put forth by Wilbur H. Siebert between 1896 and 1951 in several volumes. That idea has given way to the modern understanding of the fragmented character of the Underground Railroad, a critique that started with Larry Gara in the 1960s. The Railroad was strongest in Northern areas like Cincinnati, Detroit, Philadelphia, Boston, and Rochester, but it did not help Blacks through the most hazardous section of their voyage--the slaveholding South. The help fugitives received was often from Black allies, not self-sacrificing white abolitionists who ran only a modest risk for assisting. It was the fugitives, not the abolitionists, who played the key role in engineering their own escape and risked the gravest repercussions. Due to the limited scope of the Underground Railroad, fugitives had to rely heavily on themselves and on Black communities for successful travel; that was the organized conspiracy. Even so, Southerners believed their own mythology that it was the abolitionists and not the enslaved themselves who were generating the fugitive runaway crisis (Siebert, 2006; Gara, 1996; Blight, 2006). They deemed that Blacks were too "stupid" to make it to the American North, Canada, or elsewhere on their own cognition. It had to be those damn abolitionist Yankees or sailors causing Blacks to run away. Whites essentially reckoned that "their Negros were happy" and did not possess the technical skills to flee. Or did they?

\section{Visions of Future Freedom and Superhero-Like Flights}

Enslaved Blacks dreamed and planned futures of freedom and used technology to "teleport" them to spaces where they could live emancipated and seek equality (Phillip, 2015). On the minds of Blacks, was the freedom to have control over their bodies, to pick a mate, to parent children, to travel at will, to be educated, and to advance well beyond 
their present state. Blacks, in the bleakness of slavery, envisioned and were convinced that freedom was a part of their future. Frederick Douglass explained, "I longed to have a future--a future with hope in it," adding "I formed many a plan for my future, beginning and ending in the same determination...to find some way of escape from slavery." He ended My Bondage and My Freedom by stating "I shall labor in the future, as I have labored in the past, to promote the...elevation of the free colored people" (Douglass, 1855, 95, 153, 405). The word "future," though difficult to envision and "thoughts of grandeur," was a part of the Black lexicon, and a source of their fortitude. It gave them the opportunity to ponder the what-ifs and what is out there? These futurologists and technocrats present circumstances was not their conclusion or future, but the world they desperately desired could be defined in the mind and accomplished with time.

William Wells Brown of Kentucky eager to break the chains binding him explained "the trials of the past were all lost in hopes for the future. The love of liberty... had been burning in my bosom for years." Brown's obsession with running away only increased with time. "My escape to a land of freedom now appeared certain," he asserted on the eve of his getaway, "and the prospects of the future occupied a great part of my thoughts." Once he reached the American North Brown, a committed futurist, worked on Lake Erie steamboats that ushered Blacks to new lives in Canada. He later wrote the novel Clotel, considered to be the first crafted by an African American. Driven by the force of future, Brown used literary prose and the power of steam to transform Black lives - his pipedreams literally became reality (Brown, 1849, 90, 92, 96 \&103-108; Brown, 1853; Gordon-Reed, 2008). The very act of writing a slave narrative was done, as Harry Smith of Kentucky explained, "with the full intention of enlightening the public and future generations on the subject of slavery." Smith, enslaved for fifty years before venturing to Indiana and then to Michigan possessed the foresight "to have his history written for future generations to read" (Smith, 1891, 5-6; Gates, 1984; Andrews, 2019, 1988). Smith wanted his life to be accessible to the contemporary world and he understood that history is not just events that occurred in the past, but it can be a record that guides the future.

For Rev. Charles Thompson faith and hope in the future helped him to survive enslavement in the Lower South. As the minister explained, "My meditations sustained me through all my trials and hardships, and I plodded my weary way along with God in my heart and bright hopes for the future." He held fast to Holy Scripture, where St. Paul wrote in Hebrews that "faith is the substance of things hoped for, the evidence of things not seen" (Thompson, 1875, 79; Hebrews 11:1-6, King James Version). Nonetheless, before Black fugitives could attain future "grandeur," they had to make the stark journey to "the outer spaces of slavery" and be tested in every way imaginable. "We started with the brightest visions of future independence," escapee William Parker of Maryland and his accomplices did "but soon they were suddenly dimmed by one of those unpleasant incidents which annoy the fugitive at every step of his onward journey" (Parker, The Atlantic Monthly, Vol. XVII, February 1866, 158).

All enslaved people that ran away were brave, but some displayed staggering gall and liberty from mental slavery in the course of fleeing that it is frankly legendary. For these individuals to "act as if" emancipation was won represents an optimism of future freedom (Adler \& Ansbacher, Ansbacher, 1979). They were not just running from being beaten or sold, these Blacks had a philosophical perspective for example on God-given "inalienable" rights, Enlightenment ideas, or a critique of the injustice of unpaid labor. And, the manner in which they fled was shocking, audacious, and brazen. For the majority of escapees, sweaty palms, racing hearts, and sheer terror were inherent parts of the passage, but some like Harriet Tubman and Henry "Box" Brown, seemed to be superheroes whose deep-seated conviction gave them superpowers. In fact, Charles Ball, Henry Bibb, Moses Roper, Venture Smith and a half dozen others used the word "Adventures" in the title of their slave narratives (Ball, 1837; Bibb, 1849; Bruner, 1918; Jones, 185?; Love, 1907; Neilson, 1847; Roper, 1838 \& 1848; Smith, 1798 \& 1897; Voorhis, 1829; Wheeler, 1839). They were not belittling their enslavement, but highlighting the uncertainty, the oddities, and the outright strength it took to take flight. It seemed more like fiction than fact. Abolitionist Samuel R. Ward simply explained "fugitives evince true heroism" (Ward, 1855, 169; Douglass, 1852).

What fascinates people about Harriet Tubman is her audacity to outright insist upon being free in the time that she did. A petite, Black, enslaved woman, some five-foot-tall, disabled by a blow to the head, became a notorious runaway hero, who with confidence in God, returned to the American South again and again to save others. Tubman redefined and employed characteristics deemed "weak" with might, while trampling Victorian-era stereotypes. Indeed, as historian Erica Armstrong Dunbar has asserted, "She Came to Slay" (Dunbar, 2019). Just because Tubman was illiterate, even in freedom, that did not make her a fool; the theory of multiple intelligences reveals that she could read people, landscapes, and the night sky, which was the skill-sets she needed to undermine captivity. As Philadelphia abolitionist William Still explained of Tubman, "The idea of being captured by slave-hunters or slave-holders, seemed never to enter her mind. She was apparently proof against all adversaries" (Still, 1872, 540; Hobson, 2014; Hall, 2003). These kinds of descriptions of Tubman, though perhaps fabricated to a degree, add to her legacy as a direct-action protagonist who took courageous steps to lead people to greater liberty.

The superhuman stories circulated around figures like Tubman served a particular purpose that is shared by superheroes; by making them larger than life, these stories increase their power. Harriet Tubman's stature was great 
because she believed the future could be now (that is, the mid-1800s). She built social networks in the South and North, took advantage of the trains in the "transportation revolution," and the Niagara Falls Suspension Bridge to move people across the American-Canadian border (Taylor, 1951; Scheiber \& Salsbury, 1977; Glazebrook, 1938). The Buffalo Morning Express called the Niagara Fall overpass "one of the grandest accomplishments of modern engineering skill." (March 24, 1855). Tubman used the Niagara Falls Suspension Bridge so often that she "knew by the rise of the center of the bridge, and the descent immediately after, the line of danger was passed" (Bradford, 1886, 28; Broyld, 2014). Just the act of running away was heroic and miraculous, but those such as Tubman, with exceptional motivation and weaponry, seemed to possess superhero-like exploits.

Others invoked the same spirit and embodied the saying of "fake it "til you make it" (Adler \& Ansbacher, Ansbacher, 1979; Byrne, 2006; Nielsen, 2015). This colloquialism was part performance, therapy, and liberation Afrofuturism to initially "fake" to eventually transition faith and fantasy into a tangible reality. The "faking" allowed for survival of enslavement and all of its abuses, but the "making it" asserted the fortitude of resistance and the tenacity of escaping bondage and seeking to flourish in universal rights, liberties, and immunities, though these elements, vividly visualized and pursued, had not yet materialized. Look at Henry Bibb, who escaped slavery, and explained that after taking passage on a steamboat "I then walked as gracefully up [the] street as if I was not running away...my object was to go to Canada" (Bibb, 1849, 50). Bibb asserted that he "learned the art of running away to perfection" (15). His courage made him appear to be a freeman going about his business. Even the bravery of traveling by daylight, instead of at night, exemplified a type of innocence. When John W. Lindsey was on a steamboat bound for Pittsburgh, a Black cook asked him if he was free. Lindsey told the man that he "had heard of a man in Maryland who got rich by minding his own business and that he would find it for his own interest to attend to his own affairs" (Drew, 1856, 53; Broyld, 2017). Although Lindsey reacted with a humorous tale, he knew this was a serious matter. Anyone could betray a fugitive in exchange for a slavecatcher's reward, so maintaining a level of secrecy was key—but some were overcome with moxie.

When caught in the act of escaping the American South, William A. Hall, who eventually made his way to Dresden, Canada West, responded with boldness. Asked if he was a runaway, he replied sarcastically, "No-I am walking away." Asked for his pass to prove his legal status, he answered: "Do you suppose men need a pass in a free country." When the questioning continued "I suppose you run away--a good many fugitives go through here, and do mischief." Hall playing freedman explained, "I am doing no mischief--I am a man peaceable, going about my own business." (Drew, 1856, 222-223). Such actions embody the notion of W.E. B. Du Bois's "Unapologetic Blackness" to forcefully insist upon what was rightfully yours without reluctance or total fear of the cost (Du Bois, The Crisis, 1914). This shook the anxiety fantasy of whites to realize that enslaved Blacks were not simply unintelligent "Sambos" (the Uncle Remus, Jim Crow, and Uncle Tom figures who represented the childlike, faithful, submissive, and superstitious enslaved), but rather "Nats" (named after Nat Turner and represented enslaved persons cosmetically obedient, who were revengeful, bloodthirsty, cunning, treacherous, and savage) capable of intelligently raging against the machine of the "peculiar institution" (Blassingame, 1979, 223-248).

\section{Usage of Tools and Technology by the Black Inner Geek}

It took technical thought and technology for many Blacks to travel towards liberty lines. Their usage of the railroad, the steamboat, and other means of escape made them science lovers and techies, especially when technology moved them to freedom faster. But the Black "inner geek" could not totally be revealed because it was illegal for Blacks to read and write and displays of intelligence were met with punishment (Eglash, 2002; Kendall, 2011). Exhibiting knowledge could result in being sold away from family and friends, flogging, and even death. Nonetheless, the ears of Blacks were keen to the instruments and agents of movement and change. Fugitive usage of technology required improvisation and adaptability otherwise capture was the outcome. The travel of fleeing Blacks was not a simple trip from point A to point B. For instance, many Blacks exited trains and ships early to avoid recapture by agents or they stayed off main streets and utilized the "geography of resistance" to sidestep trouble (LaRoche, 2014; Schoolman, 2014).

The North Star was the chief guiding light. A compass was a great asset, scores of Blacks knew how to use them. Also finding sailors and boatmen, particularly those of African descent, were just as an effective alternative, they could read the night sky and the compass. The Black sailors of the Underground maritime, which historian Jeffrey Bolster referred to as "angels of liberty," were a trusted entity for escapees seeking assistance out of "Babylon" (Bolster, 1997, 190-191). These well-travelled and worldly sailors provided key information and aided escapees to the point that they were outright feared and even jailed when their vessels landed in Southern ports (Schoeppner, 2013). The fugitive desire to use modern mechanical inventions and alternative technologies or "fugitive science" was ubiquitous, though Blacks were considered static, unlearned, and unsophisticated, that was until they were gone and 
unable to be found. The irony about this all is that Africans made long-standing contributions to science and astronomy in the "Old World" that were interrupted by slavery, but not entirely severed or irreparable in the "New World" (Rusert, 2017; Cerami, 2002).

If the North Star was not visible, informed travelers found other means to forage their way out of bondage. Solomon Mosley and Jesse Happy in the late 1830s both escaped from Kentucky to British Canada by using their masters' horses (Frost, 2007, 239-246; Murray, 2000; Zorn, 1957). Although, it was great to ride the horse of flesh and blood, as more trains crisscrossed the nation Blacks modernized and sought the horse of steam and iron. William Parker, of the 1851 Christiana, Pennsylvania revolt, found his way to the North by following railway tracks from Baltimore to York, Pennsylvania (Bordewich, 2006, 327). Later, Parker used the line of the New York Central Railroad to get to Rochester, New York and boarded a steamer to Canada (Frederick Douglass' Paper, September 25, 1851; February 7, 1853). Fugitives looked to get off their feet and zoom to the next stage of the journey. Isaac Williams of Virginia en route to Canada explained "We watched as the trains came in through the day to see where the depot was, as we wished to get on the track for Philadelphia" (Drew, 1856, 66). Fugitives desired to ride on the locomotive, it was metal magic and invoked surrealism. Blacks praised developments in transportation because they could usher them out of bondage and into new liberated lives with rapidity. "The train was moving at a very high rate of speed for that time of railroad travel," Frederick Douglass explained during his escape from Maryland and travels through Delaware. He was anxious, but it took Douglass less than twenty-four hours to reach Northern soil (Douglass, 1881, 199).

Henry "Box" Brown of Virginia also wanted to pervert the means of travel to get free fast. Thereby, he and his co-conspirators, mailed himself in a wooden crate from Richmond to the Philadelphia Anti-Slavery Society (Brown, 1849; Brown, 1851). It happened after Brown's pregnant wife Nancy was sold along with their three children to North Carolina. This dangerous foray starting on March 29, 1849, in a box 3 feet long by 2 feet 8 inches deep by 2 feet wide, transported Brown efficiently by wagon, railroad, steamboat, ferry, and was completed in twenty-seven hours. Brown, thirty-four-years old and 200-pounds, insightfully with the help of Samuel Smith sent himself express mail. Scholar Hollis Robbins proclaimed, "the role of government and private express mail delivery is central to the story and the contemporary record suggests that Brown's audience celebrated his delivery as a modern postal miracle" (Robbins, 2009,6 ). This speaks to the inventiveness and practical skills, Blacks possessed to undertake such a shrewd endeavor. The instructions on the package of "dry goods" informed: "handle with care" and "this side up," both of which were not adhered to. The journey was rough in the box, but the "virtual casket" lined in cloth held its integrity (Brown, Newman, \& Gates, 2002, ix-x). Brown inside carried with him water and a few biscuits and managed to avoid detection on the outside. Miraculously, he survived by using the most proficient mechanisms to close the gap between the American South and North-- express mail. Douglass fearful of an "Upper-ground railroad" did not want the news of how Brown fled printed, he explained discontentedly it "attracted slaveholding attention to the manner of his escape, we might have had a thousand Box Browns" (North Star, September 28, 1849; Bordewich, 2006, 238-239).

Consider Harriet A. Jacobs of North Carolina, who hid in a storeroom crawlspace at her grandmother's house for years, before she engineered her way to Philadelphia then northward to New York City in 1842 via boat, train, and ferry (Jacobs, 1861, c.1860, 290). She spoke quite well of employing waterways and railways but was disappointed with the segregated "Jim Crow" cabins and cars that Blacks endured. Jacobs explained "swiftly the boat glided over the water" and "I had never entered a railroad car in my life, and it seemed to me quite an important event" (Jacobs, $237 \& 246$ ). However in the North, when Jacobs tried to buy a first-class rail ticket, and even offered to pay more money, she was told "O, no... They don't allow colored people," she did not get to enjoy the "romance of the rails" and rode in a "filthy box, behind white people." Jacobs proclaimed, "this was the first chill to my enthusiasm about the Free States" (Jacobs, 247-248; Pryor, 2016). Blacks wanted speedy modern and progressive transportation, as well as equal complementary treatment on their voyages.

Ellen and William Craft fled Georgia using coach, train, and steamboat. To escape, light-skinned Ellen dressed as a sickly white man and William of darker complexion played her slave. The couples ingenious plot rendered first-class seating, fine hotels, and dining with a steamboat captain. They took the rails from Macon to Savannah and the waves on several occasions until arriving in Philadelphia on Christmas Day. "As the train speeded on," toward the "City of Brotherly Love," William explained "I rejoiced and thanked God with all my heart and soul for his great kindness and tender mercy, in watching over us, and bringing us safely through. As soon as the train had reached the platform, before it had fairly stopped, I hurried out of my carriage to my master [really his wife]" and "jumped in myself" (Craft, 1860, 79). Taking the most sophisticated means of travel was the height of modernity. And Ellen's middle-class appearance, cross-dressing and racial passing performance was technically sound.

Slavery was a Stone Age and fugitives wanted to be "Black Jetsons" to push their people and the nation ahead to be better, faster, inclusive, progressive, and efficient. In Ishmael Reed's fictional Flight To Canada, the main character, "slave-poet" Raven Quickskill (point intended with the name), took a "nonstop jumbo jet" to the British colony (Reed, 1976). For real fugitive slaves, the steam-powered trains and steamboats might as well have been spaceships and spacecraft-hell Blacks would have taken an UFO up out of captivity. In fact, Sci-fi has a subgenre 
called "Steampunk" that the Underground Railroad should fit comfortably into. However, "Steampunk" stems from stringently divergent paradigms than Afrofuturism, given its postcolonialist critiques that celebrate empire and it is notoriously silent on race. It employs steam-power technology from the old American "Wild West" and the Victorian Eras as framework to tell alternative stories about the explosion of invention and exploration. This subgenre of "retrofuturism" features elegant brick homes, elaborate carriages, stylish clothing and the aristocratic Victorian era behavior all fueled and fashioned by the technological developments of steam (Taddeo \& Miller, 2013; Rose, 2009). It was within this "Steampunk" timeframe that the Underground Railroad developed and Blacks made good use of steam engines. "The swift running steamer," fugitive Bibb celebrating its might, "wafted my body beyond the tyrannical limits of chattel slavery." (Bibb, 1849, 169-170). The writers and artists of "Steampunk" must get fully on board to deconstruct empire, contextualize race, and employ the Underground Railroad.

Scholar John Michael Vlach explained that locomotives, also powered by steam, "with such inspirational names as Rocket, Racer, Hercules, or Giant suggested the unparalleled power of the train" (Vlach, 1991). Using these vehicles proved that Blacks could keep pace with the "hi-tech" world of the 19th century. Fugitives grasped that traveling by foot, horse, and sailboat were analog, though they did not totally rule them out, but they desired digital "steam" speeds to stay ahead and competitive with their pursuers. The railroad changed the American physical and psychological landscape compressing time and space between "slave" and "free" zones. Tech was a part of fugitive's travel plans and nimbleness, they were praised, divine devices that could bring deliverance from the shackles of slavery.

Since fugitives were "commodities" worth a great deal of money, they were pursued aggressively by white posses, law enforcement, and slave catchers and their bloodhounds. They needed tactics, technology, and weaponry to counter their antagonists. Runaways avoided dogs by rubbing red onion or spruce pine on the soles of their shoes or scattering pepper or spices over the grounds they traversed (Williams \& Goldie, 1885, 10). This retarded the ability of hounds to successfully sniff out escapees, but these ploys were not a cure-all, they only brought fugitives valuable time to get ahead (Franklin \& Schweninger, 2000, 162). The Black fugitive gizmos and gadgets to run did not have flash and flare; sheer effectiveness was the goal. Samuel R. Ward simply explained "the well-trained bloodhound [is]--a dog educated like an American, and by an American, to hate and worry a Negro" (Ward, 1855, 163-164). Unquestionably, dogs were part of the repressive machinery of bondage and tools of their masters used to tear flesh from bones. Moreover, slave possession of firearms was a crime punishable by death in Southern states, still fugitives usually carried a gun, a knife, or a makeshift weapon for defense on their journey out of slavery. Whites were not the only ones who believed in the right to safeguard their liberty and the right of self-defense against the tyrant with revolver or rifle (Carter Jackson, 2019). Blacks used "fugitive science" and any tools of modernity they could utilize to obtain freedom.

\section{The Outer Spaces of Slavery}

For Blacks in the American South any place without slavery must have sounded and felt like outer space (White, Piper, Nelson, Kemp \& Muhammad, 2001; Kilgore, 2003; Nama, 2008). They would willingly inhabit those places if given the opportunity - the American North, Canada, Africa, Europe, or elsewhere. "Slave holders sought to impress their slaves" Frederick Douglass explained "with a belief in the boundlessness of slave territory and their own limitless power" (Stauffer, 2008, 46). When Blacks in bondage grasped that there were spaces where they could live "free" or in the "safety" of a rival Empire, that became the new world they sought. Slaveholders also attempted to brainwash Blacks to think that places where slavery had been abolished were untrue, too far, post-apocalyptic, or just as bad as the American South. Some fugitives dreamed of Canada, others wanted to reach Africa or Haiti, and a number of Blacks wandered to several places seeking to find greater latitude in the "outer spaces of slavery."

Places without slavery were the cosmos, and fugitives had to some degree time-travelled when they abided within them. These spaces had "evolved" past the static slave-labor South. Blacks praised these regions and nations for their legal emancipation, despite them being racially coarse, segregated, and alienating. They navigated life in these newfound galaxies by avoiding the black holes and finding the stars. Although, the outright ownership of Black bodies was low to none in these spaces, the sense of its presence was there and equality was lacking; thus, destroying their utopian visions. Blacks realized as Sun Ra explained: "Space is not only high, it's low. It's the bottomless. There's no end to it" (Sun Ra, 1974; Bell 1992, Fawaz, 2012, 1103-1122). Likewise, the bigotry and segregation in the American North did not cease once fugitives arrived; racism was a transcending sentiment and having the right to vote was rare outside of New England. The racial and political tension in the North was overshadowed by the brutality of the South, yet that tension should not be understated. For example, from 1834 to 1841 in New York, Ohio and Pennsylvania alone some six race riots took place (Kerber, 1967; Feldberg, 1980). The millions of German and Irish immigrants flooding into the urbanizing North fueled even more clashes as each "undesirable" European group competed with Blacks for 
low-paying jobs and often found themselves crammed into nearby slums. Still, fugitives reasoned the "bottomlessness" of space or being as historian Steven Hahn explained "slaves at large" in the North was better than being Southern human "merchandise" (Hahn, 2009, 1-54).

Fugitive Andrew Jackson, who left Kentucky after more than twenty years of bondage, was hotly pursued on his northward journey, but he settled in Illinois and then Wisconsin. Jackson explained, "I am sometimes asked, how we learn the way to the free States?" "My answer" he expounded, "is that the slaves know much more about this matter than many persons are aware. They have means of communication with each other, altogether unknown to their masters, or to the people of the free states--even the route of some who have escaped is familiarly known to the more intelligent ones." This underscored the "Negro grapevine" and silent sabotage that was happening just beneath the surface in the slave community. They felt justified in reaching "outer space," just as the Israelites who fled from captivity in Egypt. "If it was right for the revolutionary patriots to fight for liberty," Jackson concluded, "it was right for me" (Jackson, 1847, 13-15). With Biblical and philosophical vindication as well as coded data, runaways were ready to blast off.

Some Blacks ironically found the outer spaces of slavery right within the American South. After all, it was the goal of Blacks to reshape the boundaries of slavery, so it would be abolished in every space. Scores in the Deep South acquired freedom by losing themselves in the free Black communities of cities like New Orleans and Charleston. Enslaved people found safety in the remote areas of the Great Dismal Swamp, which borders Virginia and North Carolina, as well as the Florida Everglades (Winsboro and Knetsch, 2013; Alexander, Newby-Alexander, and Ford, 2008, 85-112). Bands of maroon societies congregated in these areas, and in the Sea Islands of the Carolinas, Georgia, and Northern Florida. In addition, escaped enslaved people sometimes trusted Native American groups, such as the Seminoles, to provide sanctuary and protection (Hahn, 2009, 26; Diouf, 2014). Other enslaved people in the South used an "absentee" run off status, in which they left for a few days or weeks hiding out in the region, only to return later when the situation might be more favorable. A larger number of Blacks in the Deep South utilized this runaway model (Franklin \& Schweninger, 2000, 98-101).

However, for the majority, entry to the "outer spaces of slavery" required venturing out of the South and crossing regional or national borders to change their circumstances. Black fugitives headed south to the border of Mexico or to the Caribbean islands via maritime routes (Kelley, 2004; Winsboro \& Knetsch, 2013). In the Upper South, particularly in Maryland, Virginia, and Kentucky, Blacks fled to the American North and British Canada. The majority of Black runaways did not stay in the first place they reached; they moved around in space. For instance, once William and Ellen Craft reached Philadelphia, they had to decide weather to stay in the American North or go to Canada or Europe. Leading local abolitionists advised them to go to Boston, assuring the Crafts that it was nearly impossible to be taken back into slavery from there. So they settled in Boston, and found employment in the city, but after the passage of the Fugitive Slave Act of 1850, their owner sent agents to capture them. With the help of the Boston Vigilance Committee, the Crafts eluded the catchers and made their way to Maine, then Canada, and eventually to England, where they remained until after the Civil War (Craft, 1860, 81 \& 89-92).

Henry "Box" Brown also left the American North and elected to head to England. He lived there for some 25 years, working as a magician and "popular science" entertainer. He married an English woman, Jane Floyd, returned to the United States in 1875 with his family, and kept an active touring schedule as a showman. Brown spent the last decade of his life in Toronto, performing, speaking, and practicing magnetism. Hailed as a "Black Jack-in-the-Box," and billed as the "African Biologist," and "Professor Henry Box Brown," he embodied the magic of the outer spaces, while dwelling and acting on what seemed like different planets from the state in which he was born (Britt, 2017, 141142). The culture and future shock of Europe must have been daunting and being the Atlantic Ocean away from the United States was reassuring, despite Southern cotton imports that helped to fuel the British industrial revolution (Brown, 2006). Brown was never simply a manual laborer during his time of enslavement, he was hired out by his master to work in a Richmond tobacco factory. It is a misconception the Blacks had little or no access to technology; they performed a variety of skilled and semi-skilled jobs from butchers and cooks to engineers, blacksmiths, and coachmen, which revealed only a touch of their capacity to achieve (Rusert, 2017, 134-148).

Scores of Blacks wanted to inhabit the Mother continent, Africa, where they hoped its reparative nurture, values, creativity, ethnic diversity, and tech potential would heal what Western society had damaged. Africa and the vast African cultures of the continent are a key element of Afrofuturism (Bould, 2013; Anderson \& Jones, 2016, 207213). William Webb, born in Georgia and enslaved in Mississippi as a hired-hand to several owners, fled during the Civil War to Union lines. "I have a great idea about Africa," Webb explained, "I think that it is the land the Bible speaks of as flowing with milk and honey." He added, "I often think that before the end of time, the colored people will return again to their own country [continent], and I think there will be a great light shown to them in the future." He maintained ties of affection with the homeland and in freedom he had a Back-to-Africa attitude. Webb also wanted Blacks "to learn the sciences of the earth," and he spoke of "a ray of light streaming through the land....showing the colored people they have some true friends" (Webb, 1873, 74-77). This was not just small talk; it was a heightened 
realization of origins, lineage, and Afrofuturism. He was never able to reach Africa, but perhaps the most important thing he did was to contemplate it, others lived out his vision.

In 1824, Henry Highland Garnet of Maryland and eleven of his family members escaped via covered wagon when they got permission to travel to a funeral. On the trip, bondage died, and emancipation was born. Thereafter, Garnet in Afrofuturism-style, who was said to have been a descendant of African royalty, grew up in New York City, where he received a stellar education at the noted African Free School. Garnet made his name as an abolitionist, minister, and later diplomat. He once pastored a predominantly white church in Troy, New York, and he fought Jim Crow policies in railcars all over the American North. Once he was dragged off of a train in Utica for his insistence that it be desegregated. Garnet explained, "I have sufficient dignity to fill an entire car" (Pease \& Pease, 1972, 165). He supported emigration to Mexico, Liberia, the Caribbean, and looked to establish a settlement in West Africa. Garnet became the first president of the African Civilization Society a group that grew out of the self-sufficient Weeksville, Brooklyn, neighborhood founded by Blacks, and supported the "civilization and Christianization of Africa," emigration to Liberia, and "free-labor" cotton (Wellman, 2014).

By the 1850s, Weeksville had 500 inhabitants, churches, a newspaper, school, elderly home, orphan asylum, and cemetery. Weeksville provided a Wakanda-like atmosphere that evoked a Black counter narrative to society's stereotype of Black inferiority. When Garnet grew tired of the United States in 1852, he moved to Jamaica, but returned before the Civil War to support the Union in victory. As a sickly senior, he was appointed the U.S. Consul-General of Liberia, believing in its "growing greatness." His dying wish was to reach the African continent (New York Tribune, July 8, 1881; New York Times, April 4, 1880 and February, 25, 1876). In 1881, when he arrived in Monrovia, Liberia, aboard the steamer Egypt, he "was delighted with the country" (Hanes Walton, Jr., \& Clark, Rosser, and Stevenson, 1985, 72, 74-81). Garnet months later perished in his sleep and was buried in Africa's soil; a land he had deep affection for like Afrofuturists.

The long arc from slavery to attempting to reverse the Atlantic Slave Trade was difficult, but it became a tangible reality for scores of Blacks. The transition embodied the Afrofuturism pillar to recover the past and to cite the cultures of the African continent. Blacks who set out for Africa hoped to escape their status as "aliens," however they had been detached from the mothership, and untangling the threads of the Middle Passage was technically impossible. Still, in the "outer spaces of slavery," runaways searched in the midst of modernity for a sense of belonging--no matter what planet they landed on, be it Haiti, Mexico, England, the Caribbean, St. Catharines, Toronto, or Buxton, Canada West which were all key places for fugitives of the American South, but really anywhere outside the hands of bondage, a real "house of horrors," was plausible. Cora, the main character in Colson Whitehead's The Underground Railroad novel, captured the sentiment of the real fleeing fugitives best when she explained "anywhere, anywhere but where you are escaping from...find the terminus or die on the tracks" (304). Runaways understood that slavery did not have boundless horizons, and they simply wanted a new world order that was otherworldly (Sharpe, 2016).

\section{Outro}

In all, equating the Underground Railroad to Afrofuturism is boundary-pushing, but it does not overreach. Is not the point of scholarship, as sociologist Alondra Nelson explained, to engage "speculation, experimentation, and abstraction"? (Rambsy II, 2013, 205-206; Nelson, 2000, 34-37). Both the Underground Railroad and Afrofuturism rescue Blacks from the stereotype of being technophobes and asserts that they could keep pace with technoculture if they are not hi-tech hijacked (Penley \& Ross, 1991; Shaw, 2008; Carrington, 2016). Black techno-thrillers solved the ultimate algorithm-- slavery, a calculated subtraction that did not figure them into the equation. The Underground Railroad has more meaning than the metaphorical. Enslaved people were not void of technology, or simply primitive, unskilled laborers, they were driven by the chronicles of progress. Contrary to the mainstream and stereotypical thought Blacks were curious. They looked to take advantage of technology as a tool to make their getaways less troublesome and quicker (Nelson, 2002, 1). By wearing "low-tech" masks, they were able to discreetly decipher complex codes and usher themselves to the "outer spaces of slavery" with the latest technology and gadgetry.

By looking at the Underground Railroad as Afrofuturism, the understanding of the imaginative mind of the enslaved can be grasped. In the depths of slavery, Black fugitives recognized a free future was possible and that they could be "teleported" there through modern technology. This makes them some of the most inventive, astute, and cutting-edge modernist of their time. Blacks had the least resources but were the most resourceful with the little information and tools they could muster up clandestinely. By maximizing steam and other man-made mechanisms they carried themselves away from the clutches of bondage. Black runaways considered uneducated, unskilled, backward, and shiftless, amongst many other things, out thought, maneuvered, and managed to ride modern transportation to transform and invent the futures their slaveholding pursuers wanted to switch off. However, Blacks were state-of-theart and light-years ahead of what was expected but worked on a covert frequency as not to alarm owners of their 
exodus. The fugitive knew that the point of slavery was to technically unplug and power down their abilities to use technology. Just as it was in the past, the "digital divide" of today is designed to keep Blacks uninformed and as a technological underclass, which reduces their autonomy (James Stewart and Talmadge Anderson, 2007, 277-303; Chan, 2013). Black Panther's, final fight between T'Challa and Killmonger, takes place on an underground railroad paying homage to Black fugitives a prototype of Afrofuturism.

\section{References}

Adler, A., \& Ansbacher, H. L. \& Ansbacher, R.R. eds. (1979). Superiority and Social Interest: A Collection of Later Writings. New York, NY: W. W. Norton.

Alexander, W. H., Newby-Alexander, C.L. \& Ford, C.H. eds. (2008). Voices from Within the Veil: $\quad$ African Americans and the Experience of Democracy. Newcastle, U.K.: Cambridge Scholars.

Allen, S. A., \& Cherelle, L. eds. (2019). Black From the Future: A Collection of Black Speculative Writing. Clayton, NC: BLF Press.

Anderson, R., \& Jones, C.E. eds. (2017). Afrofuturism 2.0: The Rise of Astro-Blackness. Lanham, MD: Lexington Books.

Andrews, W. L. (1988). Slavery and Class in the American South: A Generation of Slave Narrative Testimony, 1840 1865. New York, NY: Oxford University Press.

Andrews, W. L. (2019). To Tell a Free Story: The First Century of Afro-American Autobiography, 1760-1865. Urbana, IL: University of Illinois Press.

Ball, C. (1837). Slavery in the United States: A Narrative of the Life and Adventures of Charles Ball, a Black Man, Who Lived Forty Years in Maryland, South Carolina and Georgia, as a Slave Under Various Masters, and was One Year in the Navy with Commodore Barney, During the Late War. New York: Published by John S.Taylor.

Barr, M. S., ed., (2008). Afro-Future Females: Black Writers Chart Science Fiction's Newest New-Wave Trajectory, Second Edition. Columbus, OH: Ohio State University Press.

Bauer, R.A. \& Bauer, A.H. Day to Day Resistance to Slavery. The Journal of Negro History Vol 27, No. 4 (Oct., 1942), pp. 388-419.

Bell, D. A. (1992). Faces at the Bottom of the Well: The Permanence of Racism. New York, NY: Basic.

Bhimull, C. D. (2017). Empire in the Air: Airline Travel and the African Diaspora. New York, NY: New York University Press.

Bibb, H. (1849). Narrative of the Life and Adventures of Henry Bibb, An American Slave, Written by Himself. New York: Author.

Blassingame, J. W. (1979). The Slave Community: Plantation Life in the Antebellum South. New York, NY: Oxford University Press.

Blight, D. W. (2018). Frederick Douglass: Prophet of Freedom. New York, NY: Simon \& Schuster.

Blight, D. W. ed. (2006). Passages to Freedom: The Underground Railroad in History and Memory. New York, NY: HarperCollins.

Bolster, J. W. (1997). Black Jacks: African American Seamen in the Age of Sail. Cambridge, MA: Harvard University Press.

Bordewich, F. M. (2006) Bound for Canaan: The Epic Story of the Underground Railroad, American's First Civil Rights Movement. New York, NY: Amistad.

Bould, M. The Ships Landed Long Ago: Afrofuturism and Black SF. Science Fiction Studies, Vol. 34, No. 2, Afrofuturism (Jul., 2007), pp. 177-186.

Bould, M., ed. Africa SF. Special Issue of Paradoxa 25 (2013), pp. 7-349.

Bradford, S. H. (1886). Harriet Tubman, the Moses of Her People. New York, NY: Geo. R. Lockwood \& Son.

Brown, C. L. (2006). Moral Capital: Foundations of British Abolitionism. Chapel Hill, NC:University of North Carolina Press.

Brown, H. B. (1849). Narrative of Henry Box Brown, Who Escaped from Slavery, Enclosed in a Box 3 Feet Long and 2 Wide. Written from a Statement of Facts Made by Himself. Boston, MA: Brown and Stearns.

Brown, H. B. (1851). Narrative of Henry Box Brown, Written by Himself. Manchester, England: Printed by Lee and Glynn.

Brown, H. B. (2002) Introduction by Richard Newman \& Forward by Henry Louis Gates, Jr. Narrative of Henry Box Brown, Written by Himself. New York, NY: Oxford University Press.

Brown, W. W. (1849). Narrative of William W. Brown, an American Slave. Written by Himself. London: C. Gilpin.

Brown, W. W. (1853). Clotel; or, The President's Daughter. London, England: Partridge \& Oakey, Paternoster Row. 
Broyld, d. j. "Justice was Refused Me, I Resolved to Free Myself:" John W. Lindsay Finding Elements of American Freedom's in British Canada, 1805-1876. Ontario History Vol. CIX. No.1, (Spring 2017): pp. 27-59.

Broyld, d. j. Fannin' Flies and Tellin' Lies: Black Runaways and American Tales of Life i British Canada Before the Civil War. American Review of Canadian Studies, Vol. 44, Issue 2, (April 2014) pg. 169-186.

Broyld, d. j. Harriet Tubman: Transnationalism and the Land of a Queen in the Late Antebellum. The Meridians: Feminism, Race, and Transnationalism special issue: Harriet Tubman: A Legacy of Resistance. Vol. 12, No. 2, (November 2014): pp. 78-98.

Bruner, P. (1918) A Slave's Adventures Toward Freedom. Not Fiction, But the Ture Story of a Struggle. Oxford, Ohio.

Butler, O. E. (1988, 2004). Kindred. Boston, MA: Beacon Press.

Byrne, R. (2006). The Secret. New York, NY: Atria Books/Beyond Words.

Carrington, A. M. (2016) Speculative Blackness: The Future of Race in Science Fiction. Minneapolis,

$\mathrm{MN}$ : University of Minnesota Press.

Carter Jackson, K. (2019). Force and Freedom: Black Abolitionists and the Politics of fViolence. Philadelphia, PA: University of Pennsylvania Press.

Cerami, C. (2002). Benjamin Banneker: Surveyor, Astronomer, Publisher, Patriot. John Wiley \& Sons.

Chan, A. S. (2013). Networking Peripheries: Technological Futures and the Myth of Digital Universalism. Cambridge: MIT Press.

Coleman, B. Race as Technology. Camera Obscura, 70, Volume 24, No. 1, (2009), pp 177-207.

Craft, W. (1860). Running a Thousand Miles for Freedom; or the Escape of William and Ellen Craft from Slavery. London: William Tweedie, Strand.

De b'Beri, B., Reid-Maroney, N \& Wright, H.K. (2014). The Promised Land: History and Historiography of the Black Experience in Chatham-Kent's Settlements and Beyond. Toronto, ON: University of Toronto Press.

De Kosnik, A., \& Feldman, K. ed. (2019). \#Identity: Hashtagging Race, Gender, Sexuality, and Nation. Ann Arbor, Michigan: University of Michigan Press

Dery, M. (1994). Flame Wars: The Discourse of Cyberculture. Durham, NC: Duke University Press.

Douglass, F. (1852). The Heroic Slave. Boston. John P. Jewett \& Company.

Douglass, F. (1855). My Bondage and My Freedom. New York: Miller, Orton \& Mulligan.

Douglass, F. (1881). Life and Times of Frederick Douglass: His Early Life as a Slave, His Escape from Bondage, and His Complete History to the Present Time. Hartford, CT: Park Publishing Co.

Drew, B. (1856). The Refugee: Or the Narratives of Fugitive Slaves in Canada. New York, NY: John P. Jewett and Company.

Dunbar, E. A. (2019) She Came to Slay: The Life and Times of Harriet Tubman. New York, NY: Simon \& Schuster.

Eglash, R. Race, Sex, and Nerds: From Black Geeks to Asian American Hipsters. Social Text 20 No. 2, (2002), pp. 4964.

English, D. K. \& A. Kim, Now We Want Our Funk Cut: Janelle Monáe's Neo-Afrofuturism. American Studies, Vol. 52, No. 4, The Funk Issue (2013), pp. 217-230.

Eshun, K. (1998). More Brilliant Than the Sun: Adventures in Sonic Fiction. NewYork, NY: Penguin Random House.

Eshun, K. Further Considerations on Afrofuturism. CR: The New Centennial Review Vol. 3, No. 2, Globalicities: Possibilities of the Globe (Summer 2003), 289-302.

Fawaz, R. Space, that Bottomless Pit: Planetary Exile and Metaphors of Belonging in American Afrofuturist Cinema. Callaloo, Vol. 35, No. 4, (Fall, 2012), 1103-1122.

Feldberg, M. (1980). The Turbulent Era: Riot and Disorder in Jacksonian America. New York, $\quad$ NY: $\quad$ Oxford University Press.

Foster, T. (2005). The Souls of Cyberfolk: Posthumanism as Vernacular Theory. Minneapolis, MN: University of Minnesota Press.

Franklin, J. H., \& Schweninger, L. (2000). Runaway Slaves: Rebels on the Plantation. New York, NY: Oxford University Press.

Frost, K. S. (2007). I've Got A Home In Glory Land: A Lost Tale of the Underground Railroad. New York, NY: Rarrar, Straus and Giroux.

Gara, L. (1961). The Liberty Line: The Legend of the Underground Railroad. Lexington, KY: University of Kentucky Press.

Gara, L. The Underground Railroad: Legend or Reality? Proceedings of the American Philosophical Society, Vol. 105, No. 3, (Jun. 27, 1961), pp. 334-339.

Gates Jr., H. L. (1984). Black Literature and Literary Theory, ed. New York, NY: Routledge.

Gilroy, P. (1993). The Black Atlantic: Modernity and Double-Consciousness. Cambridge, Mass.: Harvard University Press. 
Glazebrook, G.P. De T. (1938). A History of Transportation in Canada. New Haven, CT: Yale University Press.

Gordon-Reed, A. (2008). The Hemingses of Monticello: An American Family. New York, NY: W. W. Norton \& Company.

Goyal, Y. Runaway Genres: The Global Afterlives of Slavery. New York: NY: New York University Press, 2019.

Hahn, S. (2009). The Political Worlds of Slavery and Freedom. Cambridge, MA: Harvard University Press.

Hall, S. G. To Render the Private Public: William Still and the Selling of "The Underground Rail Road." The Pennsylvania Magazine of History and Biography, Vol. 127, No. 1, (Jan., 2003), pp. 35-55.

Harriston, K. "Forty Years Later, George Clinton's Mothership is Still Landing." The Undefeated, October 2, 2017.

Henson, J. (1858). Truth Stranger Than Fiction. Father Henson's Story of His Own Life. Boston, MA: John P. Jewett.

Hepburn, S. A. R. Following the North Star: Canada as a Haven for Nineteenth-Century American Blacks. Michigan Historical Review, Vol. 25, No. 2, (Fall, 1999), 91-126.

Hill, M. G. ed., (2019). Black Bodies and Transhuman Realities: Scientifically Modifying the Black Body in Posthuman Literature and Culture. Lanham, MD: Lexington Books.

Hobson, J. Between History and Fantasy: Harriet Tubman in the Artistic and Popular Imaginary. Meridians, Vol. 12, No. 2, Harriet Tubman: A Legacy of Resistance (2014), pp. 50-77.

Holbrook, J., \& Medupe, R.T. (2008). African Cultural Astronomy: Current Archaeoastronomy and Ethnoastronomy Research in Africa. New York, NY: Springer.

Hopkinson, N., \& Mehan, U eds. So Long Been Dreaming: Postcolonial Science Fiction \&Fantasy. Vancouver, B.C.: Arsenal Pulp Press, 2004.

Howe, S. G. (1864). The Refugees from Slavery in Canada West: Report to the Freedman's Inquiry Commission. Boston, MA: Wright and Potter.

Jackson, A. (1847). Narrative and Writings of Andrew Jackson, of Kentucky; Containing an Account of His Birth, and Twenty-Six Years of His Life While a Slave; His Escape; Five Years of Freedom, Together with Anecdotes Relating to Slavery; Journal of One Year's Travels; Sketches, etc. Narrated by Himself; Written by a Friend. Syracuse, NY: Daily and Weekly Star Office.

Jackson, S. \& Moody-Freeman, J. eds., (2013). The Black Imagination, Science Fiction and the Speculative. New York, NY: Routledge.

Jacobs, H. A. (1861, c1860). Incidents in the Life of a Slave Girl. Written by Herself. Boston: Published for the Author.

James, G. G. M. (1954, reprinted 1989). Stolen Legacy: Greek Philosophy is Stolen Egyptian Philosophy. Khalifahs Book Sellers.

James, W. Y. (2019). Imprint of Racism: White Adult Males' Transformational Experience $\quad$ from Racial Antipathy to Racial Reconciliation. American Journal of Qualitative $\quad$ Research, $\quad 3(1), \quad$ 93-116. https://doi.org/10.29333/ajqr/5813

Jameson, F. Progress Versus Utopia; or Can We Imagine the Future? Science Fiction Studies Vol. 9, No. 2, Utopia and Anti-Utopia (Jul., 1982), pp. 147-158.

Jones, T. H. (185?). Experience and Personal Narrative of Uncle Tom Jones; Who Was for Forty Years a Slave. Also the Surprising Adventures of Wild Tom, of the Island Retreat, a Fugitive Negro from South Carolina. Boston: Published by H. B. Skinner.

Jue, M. Intimate Objectivity: On Nnedi Okorafor's Oceanic Afrofuturism. Women's Studies Quarterly, 45,(1/2), 171188.

Kang, N. "As If I Had Entered a Paradise": Fugitive Slave Narratives and Cross-Border Literary History. African American Review, Vol. 39, No. 3, (Fall, 2005), pp. 431-457.

Kelley, R. D.G. (2003). Freedom Dreams: The Black Radical Imagination. Boston, MA: Beacon Press.

Kelley, S. "Mexico in His Head": Slavery and the Texas-Mexico Border, 1810-1860. Journal of Social History, 37, No. 3, (Spring 2004), 709-723.

Kendall, L. "White and Nerdy": Computers, Race, and the Nerd Stereotype. Journal of Popular Culture, 44, No. 3, (June 2011): 505-24.

Kerber, L. Abolitionists and Amalgamators: The New York City Race Riots of 1834. New York History, 48 (1967): 28-39.

Kilgore, De W. D. (2003). Astrofuturism: Science, Race, and Visions of Utopia in Space. Philadelphia, $\quad$ PA: University of Pennsylvania Press.

Kreiss, D. Performing the Past to Claim the Future: Sun Ra and the Afro-Future Underground, 1954-1968. African American Review, Vol. 45, No. 1/2, (Spring/Summer 2012), pp. $197 \quad-203$.

Kurzweil, R. (2005). The Singularity is Near: When Humans Transcend Biology. New York, NY: Viking.

LaFleur, I. "Visual Aesthetics of Afrofuturism," TEDx Fort Greene Salon, YouTude, September 25, 2011.

Langer, J. Postcolonialism and Science Fiction. New York, NY: Palgrave Macmillian, 2011. 
LaRoche, C. J. (2014). Free Black Communities and The Underground Railroad: The Geography of Resistance. Urbana, IL: University of Illinois Press.

Latham, R. (2017). Science Fiction Criticism: An Anthology of Essential Writings. Bloomsbury Academic.

Lavender, I., III. (2011). Race in American Science Fiction. Bloomington, IN: Indiana University Press.

Lebron, C. “'Black Panther' Is Not the Movie We Deserve.” Boston Review, February 17, 2018.

Love, N. (1907). Life and Adventures of Nat Love, Better Known in the Cattle Country as "Deadwood Dick," by Himself; a True History of Slavery Days, Life on the Great Cattle Ranges and on the Plains of the "Wild and Woolly" West, Based on Facts, and Personal Experiences of the Author. Los Angeles, Cal.: s.n.

Luckhurst, R. (1998). The Science-Fictionalization of Trauma: Remarks on Narrative of Alien Abduction. Science Fiction Studies, 25(1) 29-52.

Manning, P. (2010). The African Diaspora: A History Through Culture. New York, NY: Columbia University Press.

Mayer, R. "Africa As an Alien Future": The Middle Passage, Afrofuturism, and Postcolonial Waterworlds." American Studies, Vol. 45, No. 4, Time and the African-American Experience (2000), pp. 555-566.

Maynard, R. (2017). Policing Black Lives: State Violence in Canada from Slavery to the Present. Halifax, Nova Scotia: Fernwood Books.

Murray, D. (2000). Hands Across the Border: The Abortive Extradition of Solomon Moesby. The Canadian Historical Review of American Studies, 30, 186-209.

Nama, A. (2008). Black Space: Imagining Race in Science Fiction. Austin, TX: University of Texas Press.

Neilson, P. (1847). The Life and Adventures of Zamba, an African Negro King; and His Experience of Slavery in South Carolina. Written by Himself. Corrected and Arranged by Peter Neilson. London: Smith, Elder.

Nelson, A. (2002). Afrofuturism: A Special Issue of Social Text. Durham, NC: Duke University Press Books.

Nelson, A. (2000). Afrofuturism: Past-Future Visions. Color Lines, 34-37.

Nielsen, K. Fake It 'til You Make It: Why Community College Students' Aspirations Hold Steady. American Sociological Association. 884 (2015): 265-283

Okorafor, N. (2014). Who Fears Death. New York, NY: DAW Books.

Okorafor, N. (2019). Broken Places \& Outer Spaces: Finding Creativity in the Unexpected. New York, NY: Simon \& Schuster.

Pease, J. H. \& Pease W.H. (1972). Bound with Them in Chains: A Biographical History of the Antislavery Movement. Westport, Connecticut: Greenwood Press, Inc.

Penley, C. \& Ross, A. (1991). Technoculture. Minneapolis, MN: University of Minnesota Press.

Pennington, J. W.C. (1850). The Fugitive Blacksmith or Events in the History of James W.C. Pennington. $3^{\text {rd }}$ ed. London: Charles Gilpin.

Phillips, R. (2015). Black Quantum Futurism: Theory \& Practice. AfroFuturist Affair.

Pryor, E. S. (2016). Colored Travelers: Mobility and the Fight for Citizenship Before the Civil War. Chapel Hill, NC: The University of North Press.

Ra, Sun \& Smith, J. Space is a Place. Directed by John Coney. Evidence Music, 1974.

Rambsy II, H. Beyond Keeping It Real: OutKast, the Funk Connection, and Afrofuturism. American Studies, Vol. 52, No. 4, The Funk Issue (2013), pp. 205-216.

Reed, I. (1976). Flight To Canada. New York, NY: Simon \& Schuster.

Rieder, J. (2008). Colonialism and the Emergence of Science Fiction. Middletown, CT: Wesleyan University Press.

Robbins, H. Fugitive Mail: The Deliverance of Henry "Box" Brown and Antebellum Postal Politics. American Studies, Vol. 50, No. 1/2, (Spring/Summer 2009), pp. 2-25.

Roberts, A. (2000). Science Fiction. London: Routledge.

Roberts, D. (2012). Fatal Invention: How Science, Politics, and Big Business Re-create Race in the Twenty-first Century. New York, NY: The New Press.

Rollefson, Griffith J. "The 'Robot Voodoo Power' Thesis: Afrofuturism and Anti-Anti- Essentialism From Sun Ra to Kool Keith." Black Music Research Journal, Vol. 28, No. 1, Becoming: Blackness and the Musical Imagination (Spring, 2008), pp. 83-109.

Roper, M. (1838). A Narrative of the Adventures and Escape of Moses Roper, from American Slavery. Philadelphia: Merrihew

Roper, M. (1848). Narrative of the Adventures and Escape of Moses Roper, from American Slavery. With an Appendix, Containing a List of Places Visited by the Author in Great Britain and Ireland and the British Isles; and Other Matter. Berwick-upon-Tweed: Published for the author and printed at the Warder Office. 
Rose, M. Extraordinary Pasts: Steampunk as a Mode of Historical Representation. Journal of the Fantastic in the Arts, Vol. 20, No. 3, (77) (2009), pp. 319-333.

Rusert, B. (2017). Fugitive Science: Empiricism and Freedom in Early African American Culture. New York, NY: New York University Press.

Rusert, B. Delany's Comet: Fugitive Science and the Speculative Imaginary of Emancipation. American Quarterly, Vol. 65, No. 4, (December 2013), pp. 799-829.

Rusert, B. The Science of Freedom: Counterarchives of Racial Science on the Antebellum Stage. African American Review, Vol. 45, No. 3, Special issue: On Black Performance (Fall 2012), pp. 291-308.

Rushdy, A. H.A. (1999). Neo-Slave Narratives: Studies in the Social Logic of a Literary Form. New York, NY: Oxford University Press.

Scheiber, H. N. \& Stephen Salsbury, S. Reflections on George Rogers Taylor's "The Transportation Revolution, 1815-1860": A Twenty-Five Year Retrospect. The Business History Review, Vol. 51, No. 1, (Spring, 1977), pp. 79-89.

Schoeppner, M. Peculiar Quarantines: The Seamen Acts and Regulatory Authority in the Antebellum South. Law and History Review Vol. 31, No. 3 (August 2013), pp. 559-586.

Schoolman, M. (2014). Abolitionist Geographies. Minneapolis, MN: University of Minnesota Press.

Scott, J. C. (1985). Weapons of the Weak: Everyday Forms of Peasant Resistance. New Haven, CT: Yale University Press.

Scott, J. C. (1990). Domination and the Arts of Resistance: Hidden Transcripts. New Haven, CT: Yale University Press.

Seraile, W. The Brief Diplomatic Career of Henry Highland Garnet. Phylon, Vol. 46, No. 1, (1 ${ }^{\text {st }}$ Qtr., 1985), pp. 71-81.

Shadd, M. A. (1852). A Plea for Emigration or Notes of Canada West in Its Moral, Social, and Political Aspect: Suggestions Respecting Mexico, W. Indies and Vancouver's Island, For the Information of Colored Emigrants. Detroit, MI: George W. Pattison.

Sharpe, C. (2016). In the Wake: On Blackness and Being. Durham, NC: Duke University Press.

Shaw, D. B. (2008). Technoculture: The Key Concept. New York, NY: Berg.

Siebert, W. H. (2006). The Underground Railroad from Slavery to Freedom: A Comprehensive History. New York, NY: Dover Publications.

Silverman, J. A. (1985). Unwelcome Guests: Canada West's Response to American Fugitive Slaves. Millwood, NY: Associated Faculty Press, Inc.

Smith, E. D. (2012). Globalization, Utopia, and Postcolonial Science Fiction: New Maps of Hope. New York, NY: Palgrave Macmillian.

Smith, H. (1891). Fifty Years of Slavery in the United States of America. Grand Rapids, MI: West Michigan Printing Co.

Smith, V. (1798). A Narrative of the Life and Adventures of Venture, a Native of Africa: But Resident above Sixty Years in the United States of America. Related by Himself. New- London, [CT]: Printed by C. Holt, at The Bee-office.

Smith, V. (1897). A Narrative of the Life and Adventures of Venture, a Native of Africa, but Resident Above Sixty Years in the United States of America. Related by Himself. New London: Printed in 1798. Reprinted A. D. 1835, and Published by a Descendant of Venture. Revised and Republished with Traditions by H. M. Selden, Haddam, Conn., $1896 . \quad$ Middletown, Conn.: J. S. Stewart.

Spencer, R. C. "Black Feminist Meditations on the Women of Wakanda (Spoiler Alert)." Medium, February 21, 2018.

Stauffer, J. (2008). Giants: The Parallel Lives of Frederick Douglass and Abraham Lincoln. New York, NY: Twelve.

Steinskog, E. (2017). Afrofuturism and Black Sound Studies: Culture, Technology, and Things to Come. New York: NY: Palgrave Macmillan.

Stewart, J., \& Anderson, T. (2007). Introduction to African American Studies: Transdisciplinary Approaches and Implications. Inprint Editions.

Still, W. (1968, reprint from 1872). The Underground Railroad. New York, NY: Arno Press.

Szwed, J. F. (1998). Space Is the Place: The Lives and Times of Sun Ra. New York, NY: Da Capo Press.

Taddeo, J. A., \& Miller, C.J. eds. (2013). Steaming into a Victorian Future: A Steampunk Anthology. Lanham, MD: Scarecrow.

Taylor, G. R. (1951). The Transportation Revolution, 1815-1860. New York, NY: Harper \& Row.

Thompson, C. (1875). Biography of a Slave; Being the Experiences of Rev. Charles Thompson, a Preacher of the United Brethren Church, While a Slave in the South. Together with Startling Occurrences Incidental to Slave Life. Dayton, Ohio: United Brethren Publishing House. 
Tobin, J. L., Dobard, R. \& Wahlman, M.S. (2000). Hidden in Plain View: A Secret Story of $\quad$ Quilts and the Underground Railroad. New York, NY: Anchor Books.

Twain, M. (1884, 1994) The Adventures of Huckleberry Finn. Mineola, NY: Dover Publications.

Van Veen, T. C. \& Anderson, R. Black Lives, Black Politics, Black Futures. Topia: Canadian Journal of Cultural Studies, Vol. 39, (Spring 2018), pp. 5-221.

Vint, S. (2007). Bodies of Tomorrow: Technology, Subjectivity, Science Fiction. Toronto, ON: University of Toronto.

Vlach, J. M. (1991). By the Work of Their Hands: Studies in Afro-American Folklife. Charlottesville, $\quad$ VA: University Press of Virginia.

Voorhis, R. (1829). Life and Adventures of Robert, the Hermit of Massachusetts: Who Has Lived 14 Years in a Cave, Secluded from Human Society: Comprising, an Account of his

Birth, Parentage, Sufferings, and Providential Escape from Unjust and Cruel Bondage in Early Life, and His Reasons for Becoming a Recluse. Providence, RI: Printed for H. Trumbull.

Wallace, C. "Why 'Black Panther' Is a Defining Moment for Black America." The New York Times Magazine, February 12, 2018.

Walton, Jr., H., Clark, R. Rosser, J.B. \& Stevenson, R.L. Henry Highland Garnet Revisited Via His Diplomatic Correspondence: The Correction of Misconceptions and Errors. The Journal of Negro History, Vol. 68, No. 1, (Winter, 1983), pp. 80-92.

Ward, S. R. (1855). Autobiography of a Fugitive Negro: His Anti-Slavery Labours in the United States, Canada, and England. London: John Snow.

Washington, B. T. (1901). Up From Slavery: An Autobiography. Garden City, NJ: Doubleday.

Webb, W. (1873). The History of William Webb, Composed by Himself. Detroit, MI: Egbert Hoekstra.

Weheliye, A. (2005). Phonographies: Grooves in Sonic Afro-Modernity. Durham, NC: Duke University Press Books.

Wellman, J. (2014). Brooklyn's Promised Land: The Free Black Community of Weeksville, New York. New York University Press.

Wells, H.G. \& Anderson, T. eds. (2017, reprint from 1906). The Future of America: A Search After Realities. CreateSpace Independent Publishing.

Wheeler, P. (1839). Chains and Freedom: Or, The Life and Adventures of Peter Wheeler, a Colored Man Yet Living. A Slave in Chains, a Sailor on the Deep, and a Sinner at the Cross. New York: E. S. Arnold \& Co.

White, M-L, Piper, K, Nelson, A, Kemp, A.J. \& Muhammad, E.D. Aftrotech and Outer Spaces. Art Journal, Vol. 60, No. 3, (Autumn, 2001), pp. 90-104.

White, S. \& White, G. (1999). Stylin': African American Expressive Culture, From Its Beginnings to the Zoot Suit. Ithaca, NY: Cornell University Press.

Whitehead, C. (2016). The Underground Railroad: A Novel. New York, NY: Doubleday.

Williams, I. D. \& Goldie, W.F. (1885). Sunshine and Shadow of Slave Life. Reminiscences as told by Isaac D. Williams to "Tege." East Saginaw MI: Evening News Printing and Binding House.

Winsboro, I.D.S. \& Knetsch, J. Florida Slaves, the "Saltwater Railroad" to the Bahamas, and Anglo-American Diplomacy. Journal of Southern History, 79, (February 2013), 51-78.

Womack, Y. L. (2013). Afrofuturism: The World of Black Sci-Fi and Fantasy Culture. Chicago, IL: Lawrence Hill Books.

Yancy, G. (2008). Black Bodies, White Gazes: The Continuing Significance of Race. Lanham, Maryland: Rowman and Littlefield.

Yaszek, L. An Afrofuturist Reading of Ralph Ellison's Invisible Man. Rethinking History, 9, No. 2-3, (2005), 297-313.

Youngquist, P. (2016). A Pure Solar World: Sun Ra and the Birth of Afrofuturism. Austin, TX: University of Texas Press.

Yu Burnett, J. The Great Change and the Great Book: Nnedi Okorafor's Postcolonial, Post-Apocalyptic Africa and the Promise of Black Speculative Fiction. Research in African Literatures, Vol. 46, No. 4, What Is Africa to Me Now? (Winter 2015), pp. 133-150.

Zorn, R. J. Criminal Extradition Menaces the Canadian Haven for Fugitive Slaves, 1841-1861. Canadian Historical Review, 38, (December 1957), 284-294.

Zuberi, N. Is This the Future? Black Music and Technology Discourse. Science Fiction Studies, Vol. 34, No. 2, Afrofuturism (Jul., 2007), pp. 283-300. 